\title{
Efficacy of Non-Chemical Alternatives on Blue Mold of Apple under Controlled Cold Storage Conditions
}

\author{
Ziad Barakat Al-Rawashdeh ${ }^{1}$, Ezz Al-Dein Muhammed Al-Ramamneh ${ }^{1} \&$ Muwaffaq Ramadan Karajeh ${ }^{2}$ \\ ${ }^{1}$ Department of Agricultural Sciences, Al-Shoubak College, Al-Balqa' Applied University, Al-Shoubak, Jordan \\ ${ }^{2}$ Department of Plant Protection \& IPM, Faculty of Agriculture, Mu'tah University, Karak, Jordan \\ Correspondence: Ziad Barakat Al-Rawashdeh, Department of Agricultural Sciences, Al-Shoubak College, \\ Al-Balqa Applied University, Al-Shoubak, Jordan. Tel: 00962-790452203. Fax: 00962-32165035. E-mail: \\ rawaziad@yahoo.com
}

Received: January 18, 2015 Accepted: March 5, 2015 Online Published: April 15, 2015

doi:10.5539/jas.v7n5p112 URL: http://dx.doi.org/10.5539/jas.v7n5p112

\begin{abstract}
Fruits of three apple cultivars; Golden Delicious, Granny Smith and Fuji were inoculated with blue mold, Penicillium expansum, and kept under cold storage conditions for 75 days after treatment with non-chemical alternatives and the fungicide Topsin as a standard. This aimed at providing new postharvest methods for the control of blue mold incidence and severity in apple fruits. Granny Smith showed lower sensitivity to blue mold disease than Golden Delicious but Fuji was the most sensitive to the disease in relation to fruit firmness and total soluble solid content (TSS). Dipping apple fruits in yeast (Saccharomyces cerevisiae) solution at a concentration of $1 \mathrm{~g} \mathrm{~L}^{-1}$ or in hot water at $50{ }^{\circ} \mathrm{C}$ for 1 or $5 \mathrm{~min}$., or exposing them to microwave for $10 \mathrm{~s}$ resulted in an effective control of blue mold disease under controlled cold storage conditions. Calcium nitrate at 1 or $8 \mathrm{~g} \mathrm{~L}^{-1}$ did not result in an effective control of blue mold but increased the storability of apple fruits. Therefore, a combination of two or more of the alternatives may provide a long-lasting effective control of post-harvest blue mold affecting apple fruits.
\end{abstract}

Keywords: hot water, Malus domestica, microwave, post-harvest disease, yeast

\section{Introduction}

Pome fruits including apple, pear and quince are cultivated in different regions in Jordan. Domestic apple (Malus domestica Borkh.) is the main pome fruits for commercial production and found in about $5 \%$ of the total area cultivated with fruit trees in Jordan (Statistical Year Book, 2006).

Best quality of apple fruits is the demand for all consumers (Zeebroeck et al., 2007). Avoiding or delaying of post-harvest disorders and decay could be achieved with pre-harvest measures e.g. the improvement of tree nutritional status (Moore et al., 2006). Physiological disorders including superficial scald, bitter bit and physiological spot were reported to reduce the quality of marketable yield of apple fruits (Moore et al., 2006). Apple fruits are also vulnerable to a wide range of post-harvest pathogens (Penrose et al., 1989). Blue mold caused by (Penicillium expansum Link) is a major pathogen that leads to obvious yield loss during post-harvest handling and storage of apples and pears (Schirra et al., 2009; Al-Rawashdeh \& Karajeh, 2014; Penrose et al., 1989). Combination of some post-harvest treatments with cold storage was efficient in reducing the incidence and severity of apple blue mold (Al-Rawashdeh, 2013). The efficacy of post-harvest fungicides for the control of blue mold was investigated in several apple cultivars; Iprodione, imazalil, prochloraz were effective for the control of blue mold in cv. Granny Smith under suitable storage conditions (Penrose et al., 1989). Particularly, Carbendazime was effective in controlling blue mould in cultivars; Golden Delicious and Royal Gala (Al-Rawashdeh \& Karajeh, 2014). Due to the increasing global awareness of environmental hazards of pesticides and the development of resistant strains of the pathogen to fungicides frequently in use, there is a strong debate about the use of fungicides to control post-harvest diseases (Spotts \& Cervantes, 1986; Delp, 1988; Holmes \& Eckert, 1999). This led to a strict regulation imposed by many food national and international agencies and high residues in fruits are not anymore acceptable beyond fungicide tolerance limit. Chemical alternatives that are relatively safer to the environment and consumers were recently used to control disease in field and during storage. These treatments include the use of edible wax coatings, hot water, mineral salts, bread yeast (Saccharomyces cerevisiae), growth regulators and exposure to microwave heat (Schirra et al., 2009; Han, 
1990; Al-Rawashdeh, 2013; Hernández-Montiel et al., 2012; Anbukkarasi, 2013; Al-Rawashdeh \& Karajeh, 2014).

Fruits of apple cultivars used in this study were collected from the surrounding of Al-Shouback city. Al-Shouback city, located at $1300 \mathrm{~m}$ above sea level in the southern part of Jordan provides a suitable place for apple plantation. Commercial varieties which have 1000-1600 hours chilling requirement (Westwood, 1993) thrive in this environment.

Therefore, study was set up to evaluate the effectiveness of treating apple fruits with yeast, hot water, microwave heat exposure, and calcium nitrate on the incidence and severity of blue mold in Golden Delicious, Granny Smith and Fuji cultivars. The fungicide Topsin was used as a standard to compare with the non-chemical treatments.

\section{Materials and Methods}

\subsection{Fruit Collection}

Fruits of apple cultivars; Golden Delicious, Granny Smith and Fuji were collected at commercial maturity from a local orchard in Ma'an district, south of Jordan. Fruits were cold-stored at $2{ }^{\circ} \mathrm{C}$ until used in later experiments.

\subsection{Fruits Inoculation and Post-Harvest Handling}

Spores of $P$. expansum were isolated from Apple fruits that were visualized by having the symptoms of blue mold as described by Al-Rawashdeh and Karajeh (2014). Collected Fruits were initially rinsed with distilled water for a few minutes, then wounded with sterilized sand and finally inoculated through dipping into a spore suspension of $P$. expansum at a concentration of 38,000 spores $/ \mathrm{ml}$. Fruits were then dipped into either the fungicide Topsin at $\left(2\right.$ or $\left.0.5 \mathrm{~g} \mathrm{~L}^{-1}\right)$, yeast $(S$. cerevisiae $)$ at $\left(1\right.$ or $\left.10 \mathrm{~g} \mathrm{~L}^{-1}\right)$, calcium nitrate at $\left(1 \mathrm{or} 8 \mathrm{~g} \mathrm{~L}^{-1}\right)$, hot water at $50{ }^{\circ} \mathrm{C}$ for $(5$ or $1 \mathrm{~min}$ ), or tap water (negative control). Fruits were also placed in a microwave oven ( $2450 \mathrm{Mhz}, \mathrm{R}-480 \mathrm{~J}$, Thailand) for 10 or $30 \mathrm{~s}$. Spores-inoculated fruits that received no further treatments were considered as (positive control). Three replicates were used for each treatment and each replicate consisted of three fruits placed in a ventilated, $20 \times 30 \mathrm{~cm}^{2}$ plastic container, and the experiment was replicated twice. Fruits were assessed for disease severity and incidence after 75 days of cold storage at $2{ }^{\circ} \mathrm{C}$ and $90 \%$ relative humidity. Disease severity represents the percentage of fruits showing disease lesions and was rated using a scale of $0-5(0$ : no lesions, 1: 1-10, 2: 11-25, 3: 26-50, 4: 51-75, 5: 76-100\%). Disease incidence was scored based on the number of rot spots that developed on each fruit.

\subsection{Evaluation of Total Soluble Solids and Firmness}

Fruit firmness and its content of total soluble solids were determined after harvest and at the end of the experiment (after 75 days of cold storage). Fruit firmness was assessed using penetrometer. The content of total soluble solids was measured with a refracto-meter using homogenized juice obtained from sampled fruits.

\subsection{Statistical Analyses}

Data were analyzed by Generalized Linear Model (GLM) procedure using SPSS (Software version 11.5; SPSS Inc., Chicago, USA). Mean separation of treatments was performed using least significance difference (LSD) at the 0.05 probability level.

\section{Results}

\subsection{Firmness and Total Soluble Solids}

At harvest time, there were significant differences among the three apple cultivars in their fruit firmness parameter which was obviously higher for Granny Smith and Fuji than that for Golden Delicious (Table 1). 
Table 1. Maturity indices as measured by fruit firmness and content of total soluble solids in apple cultivars; Golden Delicious, Granny Smith and Fuji at harvest and after treatment at the end of the experiment. The mean of all treatments was considered for each cultivar at the end of the experiment

\begin{tabular}{|c|c|c|c|c|c|c|}
\hline \multirow[b]{2}{*}{ Cultivar } & \multicolumn{3}{|c|}{ Firmness $\left(\mathrm{lb} / \mathrm{cm}^{2}\right)$} & \multicolumn{3}{|c|}{ Total Soluble Solids (TSS) (\%) } \\
\hline & At harvest & After treatment & $\begin{array}{l}\% \text { decrease in } \\
\text { firmness }{ }^{1}\end{array}$ & At harvest & After treatment & $\%$ change in $\mathrm{TSS}^{2}$ \\
\hline Golden Delicious & $10.4^{3} b^{4} A^{5}$ & $8.9 \mathrm{bB}$ & 14.4 & $16.1 \mathrm{aA}$ & $16.9 \mathrm{bA}$ & +4.9 \\
\hline Granny Smith & $12.4 \mathrm{aA}$ & $11.0 \mathrm{aB}$ & 11.3 & $11.8 \mathrm{bB}$ & $13.2 \mathrm{aA}$ & +11.8 \\
\hline Fuji & $12.7 \mathrm{aA}$ & $9.6 \mathrm{abB}$ & 24.4 & $15.7 \mathrm{aA}$ & $15.2 \mathrm{abA}$ & -3.2 \\
\hline
\end{tabular}

Note. ${ }^{1}$ Percentage decrease in firmness of studied cultivars calculated as [(firmness after treatment - firmness at harvest) / firmness at harvest $\times 100$ ];

${ }^{2}$ Percentage change in TSS of studied cultivars calculated as [(TSS after treatment - TSS at harvest) / TSS at harvest $\times 100]$;

${ }^{3}$ Means of three replicates (containers) were used for each treatment and each replicate consisted of three fruits per a container;

${ }^{4}$ Means within columns followed with the same small letters are not significantly different using LSD test at 0.05 probability level;

${ }^{5}$ Means within rows followed with the same capital letters are not significantly different using LSD test at 0.05 probability level.

Their fruit firmness was significantly reduced after treatment (Table 1) mainly by all treatments used except calcium nitrate treatment at 1 and $8 \mathrm{~g} / 1$ (Table 2). Total soluble solid content of apple fruit was significantly lower for Granny Smith than the other two cultivars (Table 1) and significantly increased in fruits that were subjected to hot water, Topsin and calcium nitrate treatments (Table 2).

Table 2. Maturity indices as measured by fruit firmness and content of total soluble solids, averaged across the three cultivars, after inoculation with the fungus $P$. expansum and subjecting to different treatments

\begin{tabular}{lll}
\hline Treatments & Firmness $\left(\mathrm{lb} / \mathrm{cm}^{2}\right)$ & Total soluble solids (\%) \\
\hline $0.5 \mathrm{~g} \mathrm{~L}^{-1}$ Topsin & $9.0^{*} \mathrm{c}^{* *}$ & $16.5 \mathrm{a}$ \\
$2 \mathrm{~g} \mathrm{~L}^{-1}$ Topsin & $10.1 \mathrm{bc}$ & $15.5 \mathrm{ab}$ \\
$1 \mathrm{~g} \mathrm{~L}^{-1}$ Yeast & $10.0 \mathrm{c}$ & $14.3 \mathrm{bc}$ \\
$10 \mathrm{~g} \mathrm{~L}^{-1}$ Yeast & $9.0 \mathrm{c}$ & $13.7 \mathrm{bc}$ \\
$1 \mathrm{~min}$. Hot water & $10.0 \mathrm{c}$ & $16.0 \mathrm{ab}$ \\
$5 \mathrm{~min}$. Hot water & $10.0 \mathrm{c}$ & $16.3 \mathrm{a}$ \\
$10 \mathrm{~s}$ Microwave & $10.3 \mathrm{abc}$ & $14.3 \mathrm{bc}$ \\
$30 \mathrm{~s} \mathrm{Microwave}^{-1}$ Calcium nitrate & $9.3 \mathrm{c}$ & $12.3 \mathrm{c}$ \\
$\mathrm{g} \mathrm{L}^{-1}$ Calcium nitrate & $11.5 \mathrm{ab}$ & $15.0 \mathrm{ab}$ \\
$8 \mathrm{~g} \mathrm{~L}^{-1}$ & $15.0 \mathrm{ab}$ \\
Inoculated control & $11.7 \mathrm{a}$ & $15.3 \mathrm{ab}$
\end{tabular}

Note. * Means of three replicates (containers) were used for each treatment and each replicate consisted of three fruits per a container.

** Means within columns followed by the same letters are not significantly different using LSD test at 0.05 probability level.

\subsection{Blue Mold Incidence and Severity}

Generally, the disease incidence of the blue mold, as the number of decay spots per a fruit, was significantly higher for cv. Fuji then for Golden Delicious and Granny Smith as indicated by the average of means for the different treatments and control (Table 3). Among treatments, 30s microwave exposure, and 1 or $8 \mathrm{~g} \mathrm{~L}^{-1}$ calcium nitrate dipping gave significantly higher blue mold incidence than the control while disease incidence was significantly lower after treating mold-inoculated apple fruits of the three cultivars by 0.5 and $2 \mathrm{~g} \mathrm{~L}^{-1}$ Topsin, $1 \mathrm{~g}$ 
$\mathrm{L}^{-1}$ yeast, 1 and $5 \mathrm{~min}$. hot water, and 10s microwave treatments (Table 3).

Table 3. Effect of post-harvest treatments on disease incidence of blue mold in apple cultivars Golden Delicious, Granny Smith and Fuji after 8 weeks of cold storage. Disease incidence was scored based on the number of rot spots that developed on each fruit

\begin{tabular}{lllll}
\hline \multirow{2}{*}{ Treatment } & \multicolumn{3}{c}{ Cultivar } & Means \\
\cline { 2 - 4 } & Golden Delicious & Granny Smith & Fuji & $1.4 \mathrm{~d}$ \\
\hline $0.5 \mathrm{~g} \mathrm{~L}^{-1}$ Topsin & $1.3 * \mathrm{bc} * *$ & $1.6 \mathrm{bcd}$ & $1.3 \mathrm{c}$ & $2.4 \mathrm{c}$ \\
$2 \mathrm{~g} \mathrm{~L}^{-1}$ Topsin & $2.3 \mathrm{abc}$ & $3.0 \mathrm{~b}$ & $2.0 \mathrm{c}$ & $2.6 \mathrm{c}$ \\
$1 \mathrm{~g} \mathrm{~L}^{-1}$ Yeast & $2.3 \mathrm{abc}$ & $2.0 \mathrm{bcd}$ & $3.3 \mathrm{bc}$ & $3.2 \mathrm{~b}$ \\
$10 \mathrm{~g} \mathrm{~L}^{-1}$ Yeast & $2.3 \mathrm{abc}$ & $1.3 \mathrm{bcd}$ & $6.0 \mathrm{a}$ & $2.1 \mathrm{~cd}$ \\
$1 \mathrm{~min}$. Hot water & $3.3 \mathrm{abc}$ & $0.6 \mathrm{~cd}$ & $2.3 \mathrm{bc}$ & $2.1 \mathrm{c}$ \\
$5 \mathrm{~min}$. Hot water & $2.3 \mathrm{abc}$ & $1.6 \mathrm{bcd}$ & $2.3 \mathrm{bc}$ & $1.3 \mathrm{~d}$ \\
$10 \mathrm{~s} \mathrm{Microwave}$ & $1.7 \mathrm{bc}$ & $0.3 \mathrm{~d}$ & $2.0 \mathrm{c}$ & $4.0 \mathrm{a}$ \\
$30 \mathrm{~s} \mathrm{Microwave}$ & $4.7 \mathrm{a}$ & $1.3 \mathrm{bcd}$ & $6.0 \mathrm{a}$ & $4.1 \mathrm{a}$ \\
$1 \mathrm{~g} \mathrm{~L}^{-1}$ Calcium nitrate & $4.7 \mathrm{a}$ & $2.6 \mathrm{bc}$ & $5.0 \mathrm{ab}$ & $3.9 \mathrm{a}$ \\
$8 \mathrm{~g} \mathrm{~L}^{-1}$ Calcium nitrate & $3.7 \mathrm{ab}$ & $5.3 \mathrm{a}$ & $2.0 \mathrm{c}$ & $3.3 \mathrm{~b}$ \\
Inoculated control & $1.7 \mathrm{bc}$ & $3.3 \mathrm{~b}$ & $5.0 \mathrm{ab}$ &
\end{tabular}

Note. * Means of three replicates (containers) were used for each treatment and each replicate consisted of three fruits per a container;

** Means within columns followed by the same letters are not significantly different using LSD test at 0.05 probability level.

Generally, the severity \% of blue mold was the highest for cv. Fuji followed by Golden Delicious and the least in Granny Smith as it is indicated by the average of means for the different treatments and control (Table 4). Lower mold severity \% was accompanied with all treatments except 30s microwave exposure, and dipping in 1 or $8 \mathrm{~g}$ $\mathrm{L}^{-1}$ calcium nitrate that did not significantly differ in their severity \% from that of the control. The use of 1 or 10 $\mathrm{g} \mathrm{L}^{-1}$ yeast, 1 or $5 \mathrm{~min}$. hot water, $10 \mathrm{~s}$ microwave have resulted in a reduction in mold severity $\%$ similar to the use of Topsin fungicide at 0.5 and $2 \mathrm{~g} \mathrm{~L}^{-1}$ on the three apple cultivars (Table 4).

Table 4. Effect of post-harvest treatments on disease severity $\%$ of blue mold in apple cultivars; Golden Delicious, Granny Smith and Fuji

\begin{tabular}{lllll}
\hline \multirow{2}{*}{ Treatment } & \multicolumn{3}{c}{ Cultivar } & \multirow{2}{*}{ Means } \\
\cline { 2 - 4 } & Golden Delicious & Granny Smith & Fuji & $22.2 \mathrm{c}$ \\
\hline $0.5 \mathrm{~g} \mathrm{~L}^{-1}$ Topsin & $13.3^{*} \mathrm{c}^{* *}$ & $16.7 \mathrm{bc}$ & $36.7 \mathrm{bc}$ & $27.2 \mathrm{bc}$ \\
$2 \mathrm{~g} \mathrm{~L}^{-1}$ Topsin & $20.0 \mathrm{bc}$ & $36.7 \mathrm{abc}$ & $25.0 \mathrm{c}$ & $30.6 \mathrm{~b}$ \\
$1 \mathrm{~g} \mathrm{~L}^{-1}$ Yeast & $26.7 \mathrm{bc}$ & $16.7 \mathrm{bc}$ & $48.3 \mathrm{bc}$ & $38.9 \mathrm{~b}$ \\
$10 \mathrm{~g} \mathrm{~L}^{-1}$ Yeast & $30.0 \mathrm{bc}$ & $18.3 \mathrm{bc}$ & $68.3 \mathrm{ab}$ & $38.3 \mathrm{~b}$ \\
$1 \mathrm{~min}$. Hot water & $51.7 \mathrm{ab}$ & $6.7 \mathrm{c}$ & $56.7 \mathrm{abc}$ & $24.4 \mathrm{bc}$ \\
$5 \mathrm{~min}$. Hot water & $21.7 \mathrm{bc}$ & $20.0 \mathrm{bc}$ & $31.7 \mathrm{bc}$ & $22.2 \mathrm{c}$ \\
$10 \mathrm{~s}$ Microwave & $30.0 \mathrm{bc}$ & $6.7 \mathrm{c}$ & $30.0 \mathrm{bc}$ & $53.9 \mathrm{a}$ \\
$30 \mathrm{~s} \mathrm{Microwave}$ & $65.0 \mathrm{a}$ & $8.3 \mathrm{c}$ & $88.3 \mathrm{a}$ & $71.7 \mathrm{a}$ \\
$1 \mathrm{~g} \mathrm{~L}^{-1}$ Calcium nitrate & $80.0 \mathrm{a}$ & $53.3 \mathrm{ab}$ & $81.7 \mathrm{a}$ & $60.6 \mathrm{a}$ \\
$8 \mathrm{~g} \mathrm{~L}^{-1}$ Calcium nitrate & $65.0 \mathrm{a}$ & $66.7 \mathrm{a}$ & $23.3 \mathrm{c}$ & $62.2 \mathrm{a}$ \\
Inoculated control & $53.3 \mathrm{ab}$ & $70.0 \mathrm{a}$ & $63.3 \mathrm{ab}$ & \\
\hline
\end{tabular}

Note. * Means of three replicates (containers) were used for each treatment and each replicate consisted of three fruits per a container;

** Means within columns followed by the same letters are not significantly different using LSD test at 0.05 probability level. 


\section{Discussion}

Among the tested apple cultivars, Granny Smith had exhibited lower sensitivity to blue mold disease than Golden Delicious whereas Fuji was the most sensitive to the disease. The sensitivity to the blue mold was negatively correlated with fruit firmness. The loss in fruit firmness in Fuji was approximately twice that reported for Golden Delicious and Granny Smith in response to the various treatments under cold storage conditions (Table 4). Fruit firmness was a cultivar-dependent factor (Nour et al., 2010; Jan et al., 2012) and obviously increased after treating the fruits with 1 and $8 \mathrm{~g} \mathrm{~L}^{-1}$ calcium nitrate. Total soluble solid content of apple fruit was relatively lower for Granny Smith than Golden Delicious and Fuji cultivars and significantly increased when the fruit was subjected to hot water, Topsin and calcium nitrate treatments.

The control of post-harvest diseases is generally based on the application of chemical fungicides. With the increasing demand of consumer for chemical residue-free products and the development of resistant pathogenic strains, the producers have extended their interest for finding effective alternative solutions (Janisiewicz \& Korsten, 2002; Kwasiborski et al., 2014). Similar to Topsin, dipping apple fruit in yeast solution at concentration of $1 \mathrm{~g} \mathrm{~L}^{-1}$ or in hot water at $50{ }^{\circ} \mathrm{C}$ for 1 or $5 \mathrm{~min}$., or exposing them to microwave for $10 \mathrm{~s}$ were effective in controlling the blue mold. Some treatments e.g. $5 \mathrm{~min}$. hot water and $30 \mathrm{~s}$ exposure to microwave can decrease fruit firmness thus increasing the susceptibility of fruit to new infection of Penicillium expansum and this situation was cultivar dependant. Water dipping of pear fruit $\mathrm{cv}$. Coscia at $50{ }^{\circ} \mathrm{C}$ for $1-2$ min resulted in $27-31 \%$ less blue mould decay, while the 4-min dip yielded 90\% less decay than in control fruit (Schirra et al., 2009). Gholamnejad et al. (2009) showed that all tested yeast isolates inhibited growth of $P$. expansum used for in vitro assay and that isolate 69 of $S$. cervisiae was the most effective in reducing the decay of apple fruits indicating its potential use as a valuable biological agent for the control of apple blue mold. Mexican lime (Citrus aurantiifolia) fruits under cold storage were effectively protected from blue mold by the yeast, Debaryomyces hansenii (Hernández-Montiel et al., 2012).

The use of calcium nitrate at $1 \mathrm{~g}$ and $8 \mathrm{~L}^{-1}$ concentration did not result in sufficient control of the blue mold despite its effects in increasing the storability of apple fruit through increasing its firmness and total soluble solid content. Thus, a combination of calcium nitrate with one or more of the effective treatments may be useful for reducing the onset and severity of the blue mold as well as for extending the storability of apple fruit (Al-Rawashdeh, 2013). The use of sodium bicarbonate was a useful approach to improve the efficacy of yeast antagonists used for post-harvest disease control (Droby et al., 2003). Pre- and/or post-harvest treatments and cold storage are needed to delay senescence through extending the storability of apple fruit and to control post-harvest decay (Schirra et al., 2009).

\section{Conclusion}

Studied apple cultivars recorded variation in their susceptibility to blue mold with Fuji being the most sensitive to the disease. Treatment of apple cultivars with Topsin $\left(0.5\right.$ or $\left.2 \mathrm{~g} \mathrm{~L}^{-1}\right)$, yeast solution $\left(1 \mathrm{~g} \mathrm{~L}^{-1}\right), 50^{\circ} \mathrm{C}$ hot water ( 1 or $5 \mathrm{~min}$ ), or microwave exposure (10 s.) were effective means for reducing the severity of blue mold disease.

\section{References}

Al-Rawashdeh, Z. (2013). Ability of mineral salts and some fungicides to suppress apple powdery mildew caused by the fungus Podosphaera leucotricha. Asian Journal of Plant Pathology, 7, 54-59. http://dx.doi.org/10.3923/ajppaj.2013.54.59

Al-Rawashdeh, Z. B., \& Karajah, M. R. (2014). Post-harvest control of apple blue mold under cold storage conditions. American Journal of Agricultural and Biological Sciences, 9, 167-173. http://dx.doi.org/10.3844/ajabssp.2014.167.173

Anbukkarasi, V., Paramaguru, P., Pugalendhi, L., Ragupathi, N., \& Jeyakumar, P. (2013). Studies on pre and post-harvest treatments for extending shelf life in onion - A review. Agricultural Reviews, 34, 256-268. http://dx.doi.org/10.5958/J.0976-0741.34.4.011

Delp, C. J. (1988). Fungicide resistance in North America. American Phytopathological Society Press, St. Paul, MN, USA.

Droby, S., Wisniewski, M. E., El-Ghaouth, A., \& Wilson, C. L. (2003). Influence of Food additives on the control of postharvest rots of apple and peach and efficacy of the yeast-based biocontrol product Aspire. Postharvest Biology and Technology, 27, 127-135. Retrieved from http://www.ars.usda.gov/SP2UserFiles/person/6167/Foodadditives and biological control.pdf

Gholamnejad, J., Etebarian, H. R., Roustaee, A., \& Sahebani, N. A. (2009). Biological control of apples blue 
mold by isolates of Saccharomyces cerevisiae. Journal of Plant Protection Research, 49, $270-275$. http://dx.doi.org/10.2478/v10045-009-0042-0

Han, J. S. (1990). Use of antitranspirant epidermal coatings for plant protection in China. Plant Disease, 74, 263-266. http://dx.doi.org/10.1094/PD-74-0263

Hernández-Montiel, L. G., Holguín-Peňa, R. J., Larralde-Corona, C. P., Zulueta-Rodríguez, R., Rueda-Puente E., \& Moreno-Legorreta, M. (2012). Effect of inoculums size of yeast Debaryomyces hansenii to control Penicillium italicum on Mexican lime (Citrus aurantiifolia) during storage. Journal of Food, 10, $235-242$. http://dx.doi.org/dx.doi.org/10.1080/19476337.2011.633350

Holmes, G. J., \& Eckert, J. W. (1999). Sensitivity of Penicillium digitatum and P. italicum to postharvest citrus fungicides in California. Phytopathology, 89, 716-721. http://dx.doi.org/10.1094/PHYTO.1999.89.9.716

Jan, I., Rab, A., Sajid, M., \& Ali, A. (2012). Response of apple cultivars to different storage durations. Sarhad Journal of Agriculture, $28, \quad 219-225 . \quad$ Retrieved from http://www.aup.edu.pk/sj_pdf/RESPONSE\%20OF\%20APPLE\%20CULTIVARS\%20TO\%20DIFFERENT \%20STORAGE\%20-184-11-Horticulture.pdf

Janisiewicz, W. J., \& Korsten, L. (2002). Biological control of postharvest diseases of fruits. Annual Review of Phytopathology, 40, 411-441. http://dx.doi.org/10.1146/annurev.phyto.40.120401.130158

Kwasiborski, A., Bajji, M., Renaut, J., Delaplace, P., \& Jijakli, M. H. (2014). Identification of Metabolic Pathways Expressed by Pichia anomala Kh6 in the Presence of the Pathogen Botrytis cinerea on Apple: New Possible Targets for Biocontrol Improvement. PLoS ONE, 9(3). http://dx.doi.org/10.1371/journal.pone.0091434

Moore, U., Karp, K., Põldma, P., Asafova, L., \& Starast, M. (2006). Post-harvest disorders and mineral composition of apple fruits as affected by pre-harvest calcium treatments. Acta Agriculturae Scandinavica Section B-Soil and Plant Science, 56, 179-185. http://dx.doi.org/10.1080/09064710500303175

Nour, V., Trandafir, I., \& Ionica, M. E. (2010). Compositional characteristics of fruits of several apple (Malus domestica) cultivar. Notulae Botanicae Horti Agrobotanici Cluj-Napoca, 38, 228-233. Retrieved from http://www.notulaebotanicae.ro/index.php/nbha/article/view/4762

Penrose, L. J., Koffmann, W., \& Ridings, H. I. (1989). Factors affecting the efficacy of post-harvest fungicide application for the control of blue mold (Penicillium expansum) in stored apple. Plant Pathology, 38, 421-426. http://dx.doi.org/10.1111/j.1365-3059.1989.tb02162.x

Schirra, M., D’Aquino, S., Migheli, Q., Pirisi, F. M., \& Angioni, A. (2009). Influence of post-harvest treatments with fludioxonil and soy lecithin co-application in controlling blue and grey mould and fludioxonil residues in Coscia pears. Food Additives and Contaminants, 26, 68-72. http://dx.doi.org/10.1080/02652030802348080

Spotts, R. A., \& Cervantes, L. A. (1986). Populations, pathogenicity and benomyl resistance of Botrytis spp., Penicillium spp. and Mucor piriformis in packinghouses. Plant Disease, 70, 106-108. Retrieved from http://www.apsnet.org/publications/plantdisease/backissues/Documents/1986Articles/PlantDisease70n02_1 06.pdf

Statistical Year Book. (2006). Department of Public Statistics, The Hashemite Kingdome of Jordan.

Westwood, M. N. (1993). Temperate Zone Pomology: Physiology and Culture (p. 523). Oregon, USA: Timber Press, Inc.

Zeebroeck, M. V., Linden, V. V., Ramon, H., Baerdemaeker, J. D., Nicolai, B. M., \& Tijskens, E. (2007). Impact damage of apples during transport and handling. Postharvest Biology and Technology, 45, 157-167. http://dx.doi.org/10.1016/j.postharvbio.2007.01.015

\section{Copyrights}

Copyright for this article is retained by the author(s), with first publication rights granted to the journal.

This is an open-access article distributed under the terms and conditions of the Creative Commons Attribution license (http://creativecommons.org/licenses/by/3.0/). 